\title{
Comparison of the Influence of Good Corporate Governance, Return on Asset, Net Profit Margin on Company Value with Corporate Social Responsibility as Moderating Variables (Empirical Study on Banking and Mining Companies Listed on the Indonesia Stock Exchange 2016-2020)
}

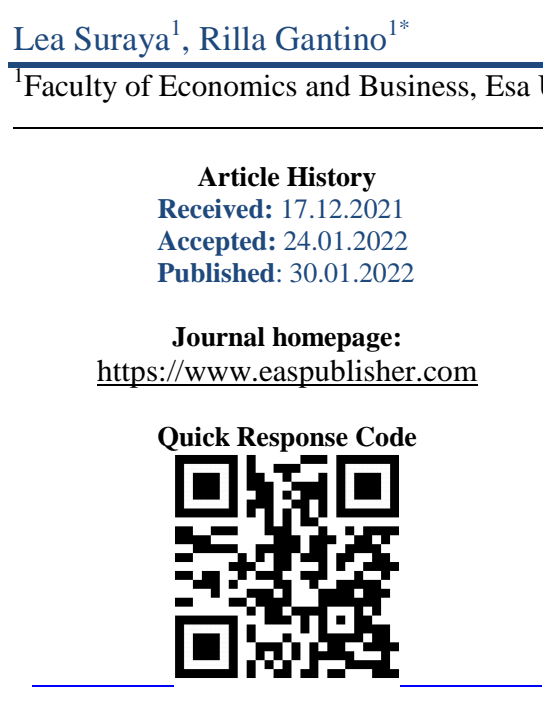

\begin{abstract}
The purpose of this study was to analyze the comparison of the influence of Good Corporate Governance, Return on Asset, Net Profit Margin on corporate value with Corporate Social Responsibility as a moderation variable of empirical studies on banking and mining companies listed on the Indonesia Stock Exchange. The study used 26 banking companies and 15 mining companies listed on the Indonesia Stock Exchange selected using the Purposive Sampling method in the period 2016-2020. This research data was analyzed using multiple regression analysis methods. The results showed that simultaneously the influence of variables Good Corporate Governance, Return On Asset, Net Profit Margin, and Corporate Social Responsibility positively affect the value of banking and mining companies. Return on Asset partially has no significant effect on the value of banking companies, while Return On Asset partially has a significant positive effect on the value of mining companies. Net Profit Margin partially had no significant effect on the value of banking and mining companies. The study also found that partial interaction of Corporate Social Responsibility variables proved to significantly moderate the relationship of the influence of Good Corporate Governance, Return On Asset, Net Profit Margin on the value of banking and mining companies.

Keywords: Good Corporate Governance, Return On Assets, Net Profit Margin, Firm Value, and Corporate Social Responsibility.
\end{abstract}

Copyright (C) 2022 The Author(s): This is an open-access article distributed under the terms of the Creative Commons Attribution 4.0 International License (CC BY-NC 4.0) which permits unrestricted use, distribution, and reproduction in any medium for non-commercial use provided the original author and source are credited.

\section{INTRODUCTION}

The bank is a financial institution that has operational activities that depend on funds entrusted by its service users or customers. Banks must have good management so that performance that produces the value of the company can increase so that it will increase public confidence. Users of bank services are individual customers (individuals) and corporate customers (non-individuals). Customer trust is affected by the good management of the company. Good management will result in good banking value and will result in good corporate value. Banking operations aim to be able to obtain profits (profits) to increase the value of the company.

The condition of the covid19 pandemic that occurred from 2020 until now makes the company increasingly need banking in carrying out its operational activities. The role of banking is increasing. One of them is as an Institution that provides credit facilities to customers (debtors). Banking provides financing facilities to companies in various sectors. One of them is the mining sector. Banking companies have a close relationship with mining companies because until now entrepreneurs or mining producers still rely on banking funding to support the growth of mining businesses. Mining is a company whose activities are directly related to natural resources. Mining companies in carrying out their activities to obtain profits to increase the value of the company. Indonesia's capital market growth is very rapid, especially in the mining and banking sectors. So that banking and mining companies have contributed to the economic growth of the Indonesian country. Mining is a company whose operational activities are directly related to natural resources. Mining has an important role as a driving force for the country's economy. Mining companies in carrying out their activities to obtain profits to increase the value of the company.

The reason for using mining and banking companies as research samples is due to several cases that occurred in several banking companies and mining companies that had an impact on company value. 
Information from the Financial Services Authority (OJK) in the first quarter of 2019 that the distribution of bank credit to mining businesses increased by $11.55 \%$ (Husaini, 2019). One of the strongest areas during 2018 was the mining business sector and the banking sector, where the composite stock price index (IHSG) continued to fluctuate, causing investors to want to invest their capital owned by banking and mining sector companies. So that companies in the banking sector and mining sector have a good contribution to the Indonesian economy. The author chooses to use a comparison of 2 (two) types of sectoral analysis units to examine the comparison. The selection of the two company sectors has never been done by previous researchers, this is a novelty in research. This study uses financial statement data for 5 years, namely 2016 2020.

This study uses several other necessary variables such as variables X1 (GCG), X2 (ROA), X3 (NPM), Y (Company Value), and variable Z (CSR) as moderating variables. According to stock index data listed on the Indonesia Stock Exchange, several companies show a comparison of the effect of Good Corporate Governance, Return On Assets, Net Profit Margin on firm value (Price Book Value) with Corporate Social Responsibility, not accompanied by an increase in firm value in several companies in Indonesia. banking and mining sectors. The following data is downloaded from the Indonesia Stock Exchange for 2016-2020.

Table 1: Banking Companies year 2016-2020

\begin{tabular}{|l|l|l|l|l|l|l|}
\hline Company Name & Year & GCG & ROA & NPM & CSR & PBV \\
\hline PT Bank Ina Perdana Tbk (BINA) & 2016 & 1.01 & 0.77 & 7.55 & 0.97 & 15.66 \\
\cline { 2 - 6 } & 2017 & 0.98 & 0.59 & 7.39 & 0.93 & 2.51 \\
\cline { 2 - 6 } & 2018 & 0.99 & 0.30 & 4.07 & 0.92 & 3.66 \\
\cline { 2 - 6 } & 2019 & 1.00 & 0.14 & 2.01 & 0.95 & 5.00 \\
\cline { 2 - 6 } & 2020 & 1.02 & 0.23 & 4.50 & 0.96 & 8.32 \\
\hline PT Bank Central Asia Tbk (BBCA) & 2016 & 0.98 & 3.05 & 40.92 & 0.91 & 3.58 \\
\cline { 2 - 6 } & 2017 & 0.99 & 3.11 & 43.37 & 0.93 & 4.33 \\
\cline { 2 - 6 } & 2018 & 1.00 & 3.13 & 45.54 & 0.97 & 4.46 \\
\cline { 2 - 6 } & 2019 & 1.02 & 3.11 & 44.75 & 0.91 & 3.87 \\
\cline { 2 - 6 } & 2020 & 1.01 & 2.52 & 41.51 & 0.95 & 4.43 \\
\hline PT Bank Rakyat Indonesia Agroniaga Tbk (AGRO) & 2016 & 1.02 & 0.91 & 10.67 & 0.97 & 6.46 \\
\cline { 2 - 6 } & 2017 & 0.99 & 0.86 & 11.22 & 0.91 & 2.42 \\
\cline { 2 - 6 } & 2018 & 0.98 & 0.88 & 12.27 & 0.89 & 1.55 \\
\cline { 2 - 6 } & 2019 & 0.97 & 0.19 & 2.48 & 0.88 & 0.52 \\
\cline { 2 - 6 } & 2020 & 1.00 & 0.11 & 1.62 & 0.93 & 4.59 \\
\hline
\end{tabular}

Source: Indonesia Stock Exchange Website (data processed by the Author)

Conceptually, the relationship between Good Corporate Governance, Return On Assets, Net Profit Margin, and firm value (Price Book Value) is positive where when Good Corporate Governance, Return On Assets, Net Profit Margin increase, it will be followed by an increase in firm value (Price Book Values). According to the data above, the increase in GCG, ROA, NPM, CSR was not matched by an increase in firm value in several companies in the banking sector.

PT Bank Ina Perdana Tbk with the issuer code BINA in 2017 and 2018 experienced a decrease in ROA successively 0.59 to 0.30 . However, it was followed by a consecutive 2.51 increase in PBV to 3.66. Return on Assets of PT Bank Ina Perdana Tbk in 2018 and 2019 decreased by 0.30 to 0.14 in a row. However, it was followed by a 3.66 consecutive increase in PBV to 5.00. The Net Profit Margin in 2017 and 2018 experienced a successive decline of 7.39 to 4.07 . However, it was followed by a consecutive 2.51 increase in PBV to 3.66. The Net Profit Margin in 2018 and 2019 experienced a successive decline of 4.07 to 2.01. However, it was followed by a 3.66 consecutive increase in PBV to 5.00.
Corporate Social Responsibility in 2017 and 2018 experienced a successive decline of 0.93 to 0.92 . However, this was followed by a consecutive 2.51 increase in PBV to 3.66.

PT Bank Central Asia Tbk with the issuer code BBCA on GCG in 2018 and 2019 experienced a successive increase of 1.00 to 1.02 . However, it was followed by a 4.46 consecutive decline in PBV to 3.87 . The Return On Assets in 2019 and 2020 decreased by 3.11 to 2.52 in a row, respectively. However, it was followed by a successive PBV increase of 3.87 to 4.43 . The Net Profit Margin in 2019 and 2020 decreased in a row from 44.75 to 41.51 . However, it was followed by a successive PBV increase of 3.87 to 4.43 .

PT Bank Rakyat Indonesia Agroniaga Tbk with the issuer code AGRO on ROA in 2017 and 2018 experienced a successive increase of 0.86 to 0.88 . However, it was followed by a 2.42 consecutive decline in PBV to 1.55. The Net Profit Margin in 2016 and 2017 experienced a successive increase of 10.67 to 11.22. However, it was followed by a successive 
decline in PBV of 6.46 to 2.42. The Net Profit Margin 2017 and 2018 experienced a successive increase of 11.22 to 12.27 . However, it was followed by a 2.42 consecutive decline in PBV to 1.55. The Return on Assets in 2019 and 2020 decreased by 0.19 to 0.11 in a row. However, it was followed by a successive increase in PBV of 0.52 to 4.59. The Net Profit Margin in 2019 and 2020 decreased by 2.48 to 1.62 . However, it was followed by a successive increase in PBV of 0.52 to 4.59.

Table 2: Mining Companies year 2016-2020

\begin{tabular}{|l|l|l|l|l|l|l|l|}
\hline No & Company Name & Year & GCG & ROA & NPM & CSR & PBV \\
\hline 1 & PT Bayan Resources Tbk & 2016 & 1.02 & 2.18 & 3.24 & 0.97 & 8.97 \\
\cline { 3 - 8 } & (BYAN) & 2017 & 0.99 & 38.03 & 31.67 & 0.90 & 5.24 \\
\cline { 3 - 8 } & & 2018 & 1.01 & 45.56 & 31.27 & 0.95 & 6.45 \\
\cline { 3 - 8 } & & 2019 & 0.99 & 18.33 & 16.83 & 0.93 & 5.62 \\
\cline { 3 - 8 } & & 2020 & 0.98 & 21.27 & 24.69 & 0.89 & 3.99 \\
\hline & PT Golden Energy Mines Tbk & 2016 & 1.02 & 9.26 & 9.10 & 0.96 & 4.77 \\
\cline { 3 - 8 } & & 2017 & 1.01 & 20.34 & 15.81 & 0.93 & 3.79 \\
\cline { 3 - 8 } & & 2018 & 1.00 & 14.34 & 9.62 & 0.92 & 3.28 \\
\cline { 3 - 8 } & & 2019 & 0.99 & 8.55 & 6.03 & 0.91 & 3.01 \\
\hline \multirow{n}{*}{3} & PT Baramulti Suksessarana Tbk (BSSR) & 2020 & 0.98 & 11.78 & 9.03 & 0.89 & 3.04 \\
\cline { 3 - 8 } & & 2016 & 0.98 & 14.90 & 11.30 & 0.89 & 2.86 \\
\cline { 3 - 8 } & & 2017 & 1.02 & 39.41 & 21.10 & 0.90 & 3.08 \\
\cline { 3 - 8 } & & 2018 & 1.01 & 28.18 & 15.57 & 0.91 & 3.16 \\
\cline { 3 - 8 } & & 2019 & 0.99 & 12.15 & 7.29 & 0.88 & 2.08 \\
\cline { 3 - 7 } & & 2020 & 0.97 & 11.59 & 9.21 & 0.86 & 1.50 \\
\hline
\end{tabular}

Source: Indonesia Stock Exchange Website (data processed by the Author)

Theoretically, the relationship between Good Corporate Governance, ROA, NPM, and firm value (Price Book Value) is positive, where when GCG, ROA, NPM have increased it will be followed by an increase in firm value (Price Book Value). According to the data above, the increase in GCG, ROA, NPM, CSR was not matched by an increase in company value in several mining sector companies.

PT Bayan Resources Tbk with issuer code BYAN in 2016 and 2017 experienced a ROA increase of 2.18 in a row to 38.03. However, this was followed by a consecutive decline in PBV from 8.97 to 5.24. The Net Profit Margin in 2016 and 2017 experienced a successive increase of 3.24 to 31.67 . However, this was followed by a consecutive decline in PBV from 8.97 to 5.24. Net Profit Margin at PT Bayan Resources Tbk in 2017 and 2018 decreased in a row from 31.67 to 31.27. However, it was followed by a 5.24 consecutive increase in PBV to 6.45. ROA in 2019 and 2020 increased by 18.33 to 21.27 . However, it was followed by a successive decline in PBV of 5.62 to 3.99 . Net Profit Margin in 2019 and 2020 experienced a successive increase of 16.83 to 24.69 . However, it was followed by a successive decline in PBV of 5.62 to 3.99 .

PT Golden Energy Mines Tbk with the issuer code GEMS on ROA in 2016 and 2017 experienced a successive increase of 9.26 to 20.34. However, it was followed by a successive PBV decline of 4.77 to 3.79 . NPM in 2016 and 2017 experienced a successive increase of 9.10 to 15.81 . However, it was followed by a successive PBV decline of 4.77 to 3.79. Good
Corporate Governance in 2019 and 2020 decreased from 0.99 to 0.98 in a row. However, it was followed by a successive PBV increase of 3.01 to 3.04. CSR in 2019 and 2020 decreased successively from 0.91 to 0.89 . However, it was followed by a successive PBV increase of 3.01 to 3.04 .

PT Baramulti Suksessarana Tbk with the issuer code of BSSR on ROA in 2017 and 2018 experienced a successive decline of 39.41 to 28.18 . However, it was followed by a 3.08 consecutive increase in PBV to 3.16. Net Profit Margin in 2017 and 2018 decreased in a row from 21.10 to 15.57 . However, it was followed by a 3.08 consecutive increase in PBV to 3.16. Net Profit Margin at PT Baramulti Suksessarana Tbk in 2019 and 2020 experienced a successive increase of 7.29 to 9.21 . However, it was followed by a consecutive decline in PBV from 2.08 to 1.50 .

\section{LITERATURE REVIEW}

Value Relevance is information as a relationship between accounting numbers and stock prices (Wibawanto, 2016). Accounting information is predicted to have a value of relevance because accounting information is statistically related to the market value of the stock. This shows the importance of accounting information to investment decision-making. Information value is the ability of information to increase the user's knowledge and confidence in financial information decision-making. The concept of value relevance of accounting information describes how investors react to the announcement of accounting information Is useful to investors in helping investors 
estimate the expected value and risk of safe returns (Scott, 2015).

Signaling theory according to Brigham and Houston (2015) is an effort by the company is giving a sign to investors about the assumptions of the company's management. Signal theory describes what should be the signs of success or irregularity of management (agent) to the owner (principal). Signs that are ability by external parties can take the form of positive signals (good news) or negative signals (bad news). Positive information provided to investors shows the company's future expectations and will have an impact on the increase in stock prices. When the stock price rises, the company's value also rises. Information provided by the company can be used by the market as a guideline for policy-making and later can have an impact on the company's value.

Disclosure of the company's social responsibility has the goal of conveying to the community the social activities carried out by the company and their impact on the surrounding community. Recognition of public legitimacy is very important in maintaining existence in the company's social environment (Ulum, 2017). Legitimacy is already a resource and the company is in dire need of the continuity of its operations. Legitimacy is considered important because the legality of the community in the company is a strategic factor for the company's development in the future. Therefore, legitimacy helps support the company's survival.

Price to Book Value Ratio (PBV) calculates the company's value from the ratio of stock market price to the company's book value. Explained that the stock price describes the value that investors must pay who prove if they have shares in the company (Purwanto dan Agustin, 2017). Therefore, the comparison of shares at a high company value can motivate investors to be confident in investing their funds because they believe that the company can grow better in the future. Price Book Value (PBV) is a ratio used to determine the fair price of a stock by calculating the last stock price at the book value of the company's last annual financial statement (Latief, 2018). The higher the Price Book Value indicates the higher the level of shareholder prosperity is the main goal of a company (Sudiani and Darmayanti, 2016). The greater the PBV ratio, the higher the company is assessed by relative financiers compared to the funds invested in the company.

Profit margins show the percentage of net income earned from sales. The increase in profit margin is considered by the company can get better profits (Kasmir, 2017). Kasmir (2017) said ROA is a comparison that describes the return on the value of assets used in the company. In addition, ROA is a better indicator of the company's profitability because it shows the effectiveness of management in utilizing assets to generate revenue. The success of a company can only be achieved with good management so that profitability increases. Ever-increasing profitability will increase its stock market price. Profitability can be measured through the Return on Asset (ROA). ROA is a ratio used to measure success in a company's operational activities to generate net income. The higher the value of ROA, the more efficient the use of the company's assets to generate a large net profit, and the position of the company will be considered the better (Hergianti, 2020).

According to Lukviarman (2016), the concept of Good Corporate Governance (GCG) is a system of a set of rules that formulate relationships between shareholders, managers, creditors, governments, employees, and other interested parties both internally and externally. The purpose of GCG is to manage and direct a business and other affairs of a company to increase business growth and accountability of the company in the form of an increase in the value of the company marked by an increase in the stock price (Lukviarman, 2016). Lukviarman (2016) considers the importance of corporate governance (CG) for stability and social welfare, namely corporate governance is corporate governance that focuses on harmony between economic and social goals between individual and group goals.

Net Profit Margin (NPM) is a ratio to measure net profit after tax to sales (Sawir, 2016). NPM considers how much profit a company earns from revenue after deducting various costs (cost of goods sold, operating expenses, interest, taxes, and so on). If the value of NPM increases, the company will become more productive and can know the company's ability to reduce its operating costs in a certain period.

Corporate Social Responsibility (CSR) activity is a form of social responsibility of the company that refers to all relationships that occur between a company and all stakeholders, consisting of customers, employees, communities, owners, governments, suppliers, and even competitors. Companies can use CSR disclosure information as a company's competitive advantage. Companies that have good environmental and social performance will be responded positively by investors through an increase in the stock price thus can affect increasing the value of the company. CSR uses the company's social responsibility as a strategy to attract investors and strengthen relationships with shareholders, as a tool to manage the company's risk and financial performance, especially in the long term (Devie et al., 2019).

\section{METHODOLOGY}

This type of causality states cause and effect between the independent variable (independent) and the study variable (dependent) as well as moderating 
variables that can strengthen or weaken the impact of the independent variable on the variable. The study of causality is a study that is used to explain the causal relationship between variables on the dependent variable in a study (Sekaran and Bougie, 2013). This type of research is used to test or analyze empirically the effect of the independent variable (Good Corporate Governance, Return On Assets, Net Profit Margin) on the dependent variable (Company Value) with a moderating variable, namely Corporate Social Responsibility.

The source of data for this study is secondary data, and secondary data comes from intermediary media. The data used includes the financial statements of banking and mining companies for 2016-2020 which are listed on the Indonesia Stock Exchange. The source of data in this study comes from the Indonesia Stock Exchange through the website www.idx.co.id. IDX was chosen as the source of data collection in this study because IDX is the largest and most comprehensive stock exchange in Indonesia. The data used include the financial statements in this study comes from data from banking and mining companies 5 years 2016-2020. The type of data used in this study is quantitative data. Quantitative data is data presented in digital form. Judging from the numbers obtained, further analysis will be carried out in data analysis. Data analysis was carried out after data collection was completed. Data analysis in this study uses parametric statistical analysis. This is because the data is measured by a comparison scale.

The sample selection method in this study is to use purposive sampling. Purposive Sampling is a technique in selecting samples using certain criteria made by researchers (Sekaran dan Bougie, 2013). Of the existing population, 26 banking companies and 15 mining companies are listed on the Indonesia Stock Exchange year 2016-2020.

Table 1: Variable Measurement

\begin{tabular}{|l|l|c|c|}
\hline Study Variables & Variable & Proxy & Scale \\
\hline $\begin{array}{l}\mathrm{X}_{1} \\
\text { Variable (independent) }\end{array}$ & GCG & GCDI: $\frac{\text { Number of GCG Disclosure items }}{\text { GCG } \text { information }} \times 100 \%$ & Ratio \\
\hline $\begin{array}{l}\mathrm{X}_{2} \\
\text { Variable (independent) }\end{array}$ & ROA & ROA: $\frac{\text { Profit After Tax }}{\text { Total Assets }}$ & Ratio \\
\hline $\begin{array}{l}\text { X3 } \\
\text { Variable (independent) }\end{array}$ & NPM & NPM: $\frac{\text { Net Profit }}{\text { Net Sales }}$ & Ratio \\
\hline $\begin{array}{l}\text { Variable (dependent) } \\
\text { V) }\end{array}$ & PBV & PBV $: \frac{\text { Market Price Per }- \text { share }}{\text { Book Value per Share }}$ & Ratio \\
\hline \begin{tabular}{l} 
Variable (Moderating) \\
\hline
\end{tabular} & CSR & CSRDI: $\frac{\text { Number of CSR Disclosure items }}{\text { CSR Information }} 100 \%$ & Ratio \\
\hline
\end{tabular}

Source: Formula Data

\section{RESULT AND DISCUSSION}

Descriptive statistics are used in describing the amount of data in this study to show the maximum, minimum, mean, and standard deviation values of each variable (Ghozali, 2016).

Table 4: Descriptive Statistical Test Results of Banking Companies

\begin{tabular}{|l|l|l|l|l|l|}
\hline & N & Minimum & Maximum & Mean & Std. Deviation \\
\hline GCG (X1) & 130 & 0.89 & 1.02 & 0.9842 & 0.02821 \\
\hline ROA (X2) & 130 & 0.02 & 7.82 & 1.3641 & 1.02430 \\
\hline NPM (X3) & 130 & 0.20 & 45.54 & 15.3714 & 10.01651 \\
\hline CSR (Z) & 130 & 0.77 & 0.97 & 0.8632 & 0.04323 \\
\hline PBV (Y) & 130 & 0.35 & 15.66 & 1.8159 & 1.75884 \\
\hline Valid N (listwise) & 130 & & \multicolumn{3}{|l}{} \\
\hline
\end{tabular}

Source: data processed by the Author

The study was 130 data with the following results:

1. PBV has a minimum value of 0.35 . The highest score was 15.66. The Mean value of 1.8159 is greater than the standard deviation value of 1.75884 , so the PBV is quite good.
2. GCG has a minimum value of 0.89 . The maximum value of 1.02 . The Mean value of 0.9842 is greater than the standard deviation value of 0.02821 the high and good sector GCG value. 
3. ROA has a minimum value of 0.2. The maximum value of 7.82. The Mean value of 1.3641 is greater than the standard deviation value of 1.02430 this ROA value has a small data distribution.

4. NPM has a minimum value of 0.20. Maximum Net Profit Margin value of 45.54 Mean value of 15.3714 greater standard deviations of 10.01651 amount of NPM value is still far from the maximum value and NPM has a small data distribution.

5. CSR has a minimum value of 0.77 maximum value of 0.97 and a Mean value of 0.8632 the resulting standard deviation value is $0.04323 \mathrm{CSR}$ value in the banking sector is quite good because it is still close to the maximum value and CSR data distribution is quite high.

Table 5: Descriptive Statistical Test Results of Mining Companies

\begin{tabular}{|l|l|l|l|l|l|}
\hline & N & Minimum & Maximum & Mean & Std. Deviation \\
\hline GCG (X1) & 75 & 0.97 & 1.02 & 1.0006 & 0.01510 \\
\hline ROA (X2) & 75 & 0.14 & 45.56 & 10.7073 & 10.02641 \\
\hline NPM (X3) & 75 & 0.21 & 38.20 & 10.4059 & 7.96466 \\
\hline CSR (Z) & 75 & 0.74 & 0.97 & 0.8700 & 0.04919 \\
\hline PBV (Y) & 75 & 0.29 & 8.97 & 1.8256 & 1.56990 \\
\hline Valid N (listwise) & 75 & \multicolumn{7}{|c|}{ Source: data processed by the Author } \\
\hline \multicolumn{7}{|c|}{}
\end{tabular}

The study totaled 75 data with the following results:

1. PBV has a Minimum value of 0.29 The highest value is 8 , the Mean Value of 1.8256 is greater than the standard deviation value of 1.56990 and the company's distribution of value is quite high.

2. GCG has a Minimum value of 0.97 maximum value of 1.02 Mean value of 1.0006 greater than the standard deviation value of 0.01510 this GCG value is quite good because it is adjacent to the maximum value and has a large data distribution.

3. ROA has a minimum value of 0.14 . The maximum value of 45.56 Mean value of 10.7073 is greater than the standard deviation value of 10.02641 the magnitude of this ROA value is less than the Mean value showing this variable has a small data distribution.

4. NPM has a minimum value of 0.21 maximum value of 38.20 and a mean value of 10.4059 greater than the standard deviation of 7.96466. The NPM mean value is still far from the maximum value and has a small data distribution.

5. CSR has a minimum value of 0.74 the largest value is 0.97 and the mean value is 0.8700 and the resulting standard deviation value is 0.04919 CSR value is quite good because it is still close to the maximum value and CSR data distribution is quite high.

\section{Normality Test Results}

The normality test is a test designed to test whether the resulting regression model is normally distributed The normality test is a test designed to test whether the resulting regression model is normally distributed (Ghozali, 2016). The normality test aims to test whether the confounding variables or residual variables in the regression model are normally distributed. The normality test aims to test whether the confounding variables or residual variables in the regression model are normally distributed (Ghozali, 2016).

In this study the researchers used the OneSample Kolmogorov-Smirnov test, using a significance level of 0.05 as the basis for decision making:

a. The significant number of the KolmogorovSmirnov Sig Test $>0.05$ means that the data is normally distributed.

b. The significant number of the KolmogorovSmirnov Sig Test $<0.05$ means that the data is not normally distributed.

The following are the results of normality testing of residual data processed by SPSS as follows:

Table 6: Normality Test Results of Banking Companies

\begin{tabular}{|l|l|l|}
\hline \multicolumn{2}{|c|}{} & Unstandardized Residual \\
\hline $\mathrm{N}$ & Mean & 130 \\
\hline \multirow{2}{*}{ Normal Parameters, } & Std. Deviation & 0.0000000 \\
\hline \multirow{2}{*}{ Most Extreme Differences } & 0.16107094 \\
\cline { 2 - 3 } & Absolute & 0.069 \\
\cline { 2 - 3 } & Positive & 0.042 \\
\cline { 2 - 3 } & Negative & -0.069 \\
\hline Test Statistic & 0.069 \\
\hline Asymp. Sig. (2-tailed) & $0.200^{\text {c,d }}$ \\
\hline $\begin{array}{l}\text { Source: data processed by the Author } \\
\text { the result is shown from the asymp. Sig (2-tailed) value in the table is } 0.200 \text { where the asymp value. Sig (2-tailed) }>0.05 \text { then it } \\
\text { can be said that the sample data is normally distributed. }\end{array}$ \\
\hline
\end{tabular}




\begin{tabular}{|l|l|l|}
\hline \multicolumn{2}{|c|}{ Table 7: Normality Test Results of Mining Companies } \\
\hline \multicolumn{2}{|c|}{$\mathrm{N}$} & Unstandardized Residual \\
\hline \multirow{2}{*}{ Normal Parameters ${ }^{\mathrm{b}}$} & Mean & 75 \\
\cline { 2 - 3 } & Std. Deviation & 0.0000000 \\
\hline \multirow{2}{*}{ Most Extreme Differences } & Absolute & 0.15136830 \\
\cline { 2 - 3 } & Positive & 0.068 \\
\cline { 2 - 3 } & Negative & 0.043 \\
\hline Test Statistic & -0.068 \\
\hline Asymp. Sig. (2-tailed) & 0.068 \\
\hline $\begin{array}{l}\text { Source: data processed by the Author } \\
\text { the result is shown from the asymp. Sig (2-tailed) value in the table is } 0.200 \text { where the asymp value. Sig (2-tailed) }> \\
0.05, \text { it can be said that the sample data is normally distributed. }\end{array}$ \\
\hline
\end{tabular}

\section{Classic Test Results}

Autocorrelation Test

The autocorrelation test is used to assess whether in the linear regression model there is a correlation between the nuisance error in the current period $(\mathrm{t})$ and the bully error in the previous period $(\mathrm{t}-1)$ (Ghozali, 2016). This study is to detect autocorrelation using the Durbin Watson model.

Table 8: Autocorrelation Test Results of Banking Company

\begin{tabular}{|l|l|l|l|l|l|}
\hline Model & R & R Square & Adjusted R Square & Std. An error of the Estimate & Durbin-Watson \\
\hline 1 & $.847^{\mathrm{a}}$ & .718 & .709 & .16363 & 1.904 \\
\hline
\end{tabular}
Source: data processed by the Author

Durbin Watson's value of 1,904 compared to a significant table value of $5 \%$ with $\mathrm{N}=130$ and the number of independent variables $(K)=3$.

Durbin Watson $=1.904$ Seen in Durbin Watson table value $\mathrm{dl}=1.6667$ and $\mathrm{du}=1.7610$. The values $\mathrm{d}, \mathrm{dl}$, and du are:

\begin{tabular}{|l|l|l|l|l|}
\hline $\mathrm{d}$ & $\mathrm{dl}$ & $\mathrm{du}$ & $4-\mathrm{dl}$ & $4-\mathrm{du}$ \\
\hline 1.904 & 1,6667 & 1,7610 & 2.3333 & 2,239 \\
\hline
\end{tabular}

$\mathrm{du}<\mathrm{d}<4-\mathrm{dU}(1,7610<1.904<2,239)$

The DU value obtained on Durbin Watson's table of $\mathrm{DU}=1.7610$ and $\mathrm{DL}=1.6667 . \mathrm{DU}=1.7610$ is less than DW $=1.904$ and less than the value $(4-\mathrm{DU})=$ 2,239 . There is no autocorrelation of the sample data.

Table 9: Autocorrelation Test Results of Mining Company

\begin{tabular}{|l|l|l|l|l|l|}
\hline Model & R & R Square & Adjusted R Square & Std. An error of the Estimate & Durbin-Watson \\
\hline 1 & $.901^{\mathrm{a}}$ & .812 & .801 & .15563 & 1.768 \\
\hline \multicolumn{2}{|l}{ Source: data processed by the Author } \\
\hline
\end{tabular}

Durbin Watson's value is 1,768 , then this value is compared to a significant table value of $5 \%$ with $\mathrm{N}=$ 75 , and the number of independent variables $(K)=3$.

Durbin Watson value of $=1.768$ Seen in Durbin Watson table obtained value $\mathrm{dl}=1.5432$ and $\mathrm{du}$ $=1.7092$. The values $\mathrm{d}, \mathrm{dl}$, and du are:

\begin{tabular}{|l|l|l|l|l|}
\hline $\mathrm{d}$ & $\mathrm{dl}$ & $\mathrm{du}$ & $4-\mathrm{dl}$ & $4-\mathrm{du}$ \\
\hline 1.768 & 1.5432 & 1.7092 & 2.4568 & 2.2908 \\
\hline
\end{tabular}

The DU value obtained in Durbin Watson's table of DU $=1.7092$ and $\mathrm{DL}=1.5432$ Means that the DU value $=1.7092$ is less than the value $\mathrm{DW}=1.768$ and less than the value $(4-D U)=2.2908$ Then there is no autocorrelation in the sample data.

\section{Multicollinearity Test}

The multicollinearity test is used to test whether there is a correlation between free variables in regression models (Ghozali, 2016). multicollinearity is a test designed to test whether the regression model finds a correlation between the independent variables (Ghozali, 2016). The way to test multicollinearity is to look at the tolerance value and the Variance Inflation Factor (VIF) value. Multicollinearity analysis was carried out by looking at the tolerance value and the Variance Inflation Factor (VIF) value, namely by looking at the tolerance value $>0.10$ and the VIF value $<10$ :

1. If VIF $>10$ or Tolerance $<0.10$, then multicollinearity occurs.

2. If VIF $<10$ or Tolerance $>0.10$, then there is no multicollinearity. The results of the multicollinearity test processed by SPSS can be seen in the table: 


Table 10: Multicollinearity Test Results of Banking
Companies
\begin{tabular}{|l|l|l|}
\hline \multirow{2}{*}{ Model } & Collinearity Statistics \\
\cline { 2 - 3 } & Tolerance & VIF \\
\hline (Constant) & & \\
\hline GCG (X1) & 0.766 & 1.306 \\
\hline ROA (X2) & 0.623 & 1.604 \\
\hline NPM (X3) & 0.617 & 1.621 \\
\hline CSR (Z) & 0.771 & 1.297 \\
\hline Source: data processed by the Author \\
\hline
\end{tabular}

The results of the variance inflation factor value of VIF value $<10$ can be said that there is no multicollinearity in the regression method. The purpose of the multicollinearity test is to test whether the value in the regression method is determined by the correlation between the independent variables. All VIF values show numbers less than 10 . And the tolerance value for all comparisons has a value of more than 0.1 , where the $\mathrm{X} 1$ variable $(\mathrm{GCG})$ is $0.776 \mathrm{X} 2$ variable ( $\mathrm{ROA}$ ) is $0.623 \mathrm{X} 3$ variable (NPM) is $0.617 \mathrm{Z}$ variable (CSR) of 0.771 which means that there is no multicollinearity problem.

\section{Table 11: Multicollinearity Test Results of Mining} Companies

\begin{tabular}{|l|l|l|}
\hline \multirow{2}{*}{ Model } & \multicolumn{2}{|l|}{ Collinearity Statistics } \\
\cline { 2 - 3 } & Tolerance & VIF \\
\hline (Constant) & & \\
\hline GCG (X1) & 0.818 & 1.222 \\
\hline ROA (X2) & 0.330 & 3.030 \\
\hline NPM (X3) & 0.343 & 2.915 \\
\hline CSR (Z) & 0.638 & 1.568 \\
\hline Source: data processed by the Author \\
\hline
\end{tabular}

According to the multicollinearity test above, it is found that the VIF value in the Collinearity Statistics column for the X1 (GCG) variable is 1,222, the $\mathrm{X} 2$ variable (ROA) is 3,030, the $\mathrm{X} 3$ variable (NPM) is 2,915 , the $Z$ variable (CSR) is 1,568 . All VIF values show a number less than 10 . tolerance in all comparisons has a value above 0.1 where the $\mathrm{X} 1$ variable (GCG) is $0.818 \mathrm{X} 2$ variable (ROA) is $0.330 \mathrm{X} 3$ variable (NPM) is $0.343 \mathrm{Z}$ variable $(\mathrm{CSR})$ is 0.638 , meaning that there is no multicollinearity problem.

\section{Heteroskedasticity Test}

Heteroskedasticity tests are performed to assess the absence of variance from residual observations from one residual observation to another in the regression model (Ghozali, 2016). The heteroscedasticity test is a test designed to assess whether a regression model is feasible to use to predict the dependent variable which is influenced by the independent variable (Ghozali, 2016). To see whether there is heteroscedasticity in the model, a scatterplot can be used to avoid heteroscedasticity regression. The basic analysis of this test is:

a. If there is a certain pattern, such as the dots that form a certain regular pattern (waveform, first widens and then narrows), it shows that heteroscedasticity has occurred.

b. If there is no clear pattern then the points will not cluster, the spread of the data points is not patterned (not wavy, not widening, then not narrowing, not widening again), and the points are above and below the number 0 or spread around the Y-axis, showing no heteroscedasticity.

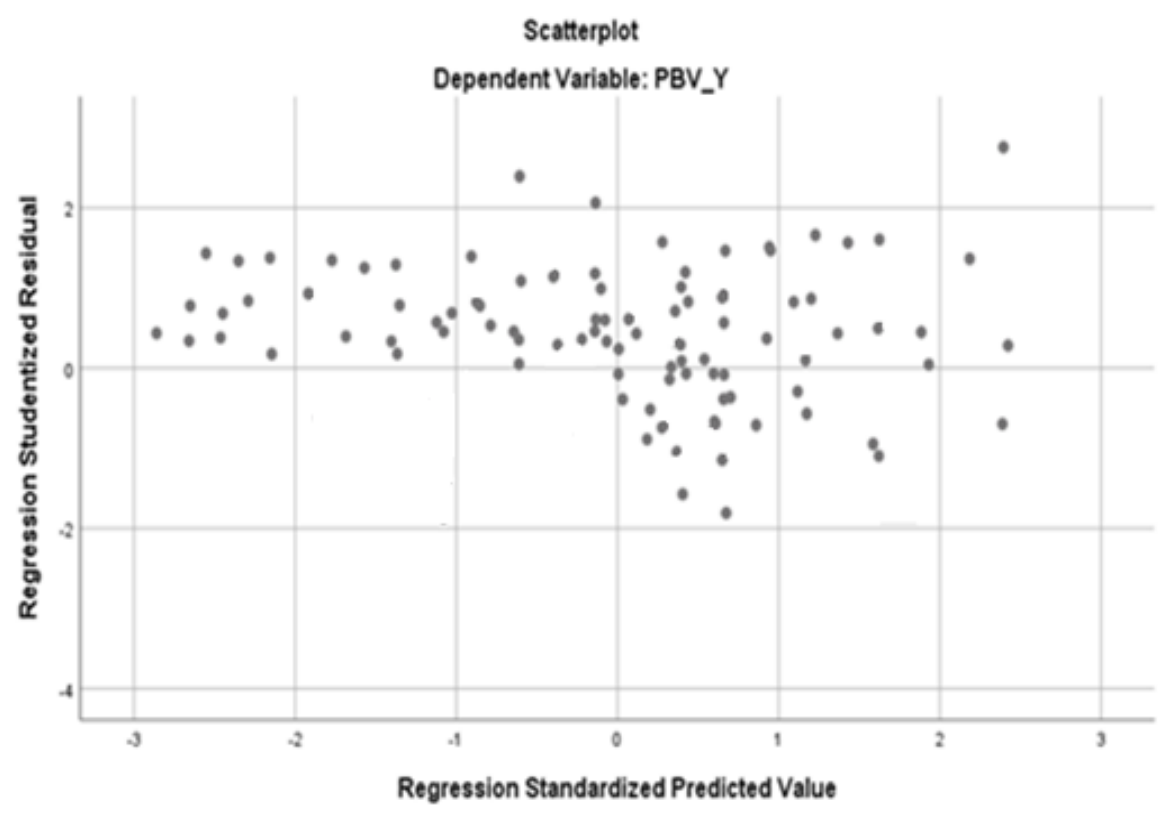

Figure 3: Heteroscedasticity Test Results of Banking Companies

Source: data processed by the Author 
The results of the test above show that if the dots in the image have spread, do not collect, and do not form a specific pattern, then the data is free from heteroskedasticity, and regression models are worth using.

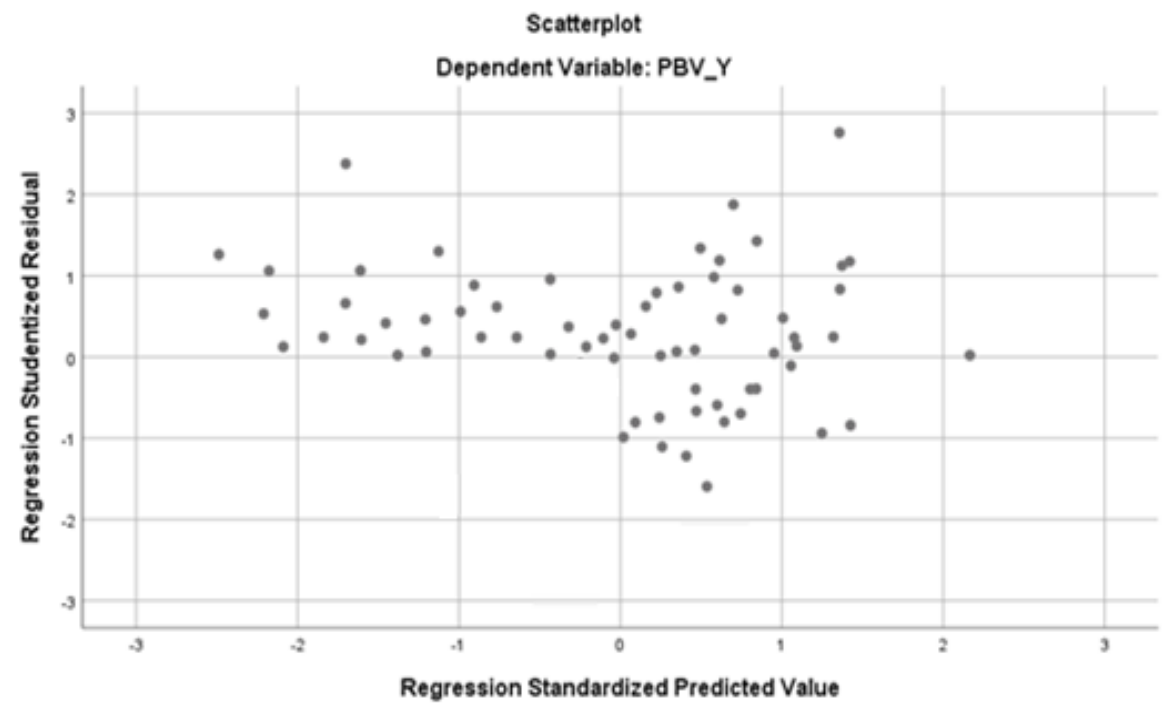

Figure 3: Heteroscedasticity Test Results of Mining Companies

Source: data processed by the Author

The results of the above test showed the points in the image have spread, do not collect in one part, and do not form a specific pattern, so the data is free from heteroskedasticity, and regression models are worth using.

\section{Hypothesis Testing Results \\ Test - F (Simultaneous Test)}

Statistical test $\mathrm{F}$ in principle shows whether all the free variables intended in the model affect simultaneously independent variables (Ghozali, 2016). The significance value used is $5 \%$. Statistical test $\mathrm{F}$ shows whether all independent variables in the model affect simultaneously independent variables. The $\mathrm{F}$ test is performed by comparing the calculated $\mathrm{F}$ value with the $\mathrm{F}$ table and looking at the significance value of 0.05 .

Table 12: F Statistical Test Results of Banking Companies

\begin{tabular}{|l|l|l|l|l|l|}
\hline Model & Sum of Squares & df & Mean Square & F & Sig. \\
\hline Regression & 8.516 & 4 & 2.129 & 79.519 & $0.000^{\text {b }}$ \\
\hline Residual & 3.347 & 125 & 0.027 & & \\
\hline Total & 11.863 & 129 & & & \\
\hline
\end{tabular}

Source: data processed by the Author

The table results show that together between independent variables and dependent variables obtained F calculates 79.519 with a significance of 0.000 so that the significance value of $<0.05$ that GCG, ROA, NPM, and CSR simultaneously positively and significantly affect $\mathrm{H} 1$ is received.

Table 2: F Statistical Test Results of Mining Companies

\begin{tabular}{|l|l|l|l|l|l|}
\hline Model & Sum of Squares & df & Mean Square & F & Sig. \\
\hline Regression & 7.306 & 4 & 1.826 & 75.404 & $0.000^{\mathrm{b}}$ \\
\hline Residual & 1.696 & 70 & 0.024 & & \\
\hline Total & 9.001 & 74 & & & \\
\hline \multicolumn{5}{|c|}{ Source: data processed by the Author } \\
\hline
\end{tabular}

Source: data processed by the Author

The table results show that the test together between independent variables and dependent variables obtained F calculates 75.404 with a significance of 0.000 so that the significance value is less than 0.05 . Based on these results, it shows that GCG, ROA, NPM, and CSR simultaneously have a positive effect and the significance of $\mathrm{H} 2$ is accepted.

\section{Test - t (Partial Test)}

The t-test shows how far the influence of one independent variable is individually in explaining the 
variation of the dependent variable (Ghozali, 2016). $0.05(\alpha=5 \%)$.

The test was carried out using a significance level of

Table 13: Statistical Test Results - $t$ of Banking Companies

\begin{tabular}{|l|l|l|l|l|l|}
\hline \multirow{2}{*}{ Model } & Unstandardized Coefficients & Standardized Coefficients & \multirow{2}{*}{ t } & \multirow{2}{*}{ Sig. } \\
\cline { 2 - 5 } & B & Std. Error & Beta & & \\
\hline (Constant) & 4.347 & 0.861 & & 5.046 & 0.000 \\
\hline GCG (X1) & 4.510 & 0.880 & 0.420 & 5.124 & 0.000 \\
\hline ROA (X2) & 0.033 & 0.030 & 0.112 & 1.124 & 0.263 \\
\hline NPM (X3) & 0.005 & 0.003 & 0.013 & 0.127 & 0.899 \\
\hline
\end{tabular}

Source: data processed by the Author

Table 14: Statistical Test Results - t of Mining Companies

\begin{tabular}{|l|l|l|l|l|l|}
\hline \multirow{2}{*}{ Model } & \multicolumn{2}{|l|}{ Unstandardized Coefficients } & Standardized Coefficients & t & \multirow{2}{*}{ Sig. } \\
\cline { 2 - 6 } & B & Std. Error & Beta & & \\
\hline (Constant) & 4.613 & 2.121 & & 2.175 & 0.033 \\
\hline GCG (X1) & 4.495 & 2.126 & 0.195 & 2.114 & 0.038 \\
\hline ROA (X2) & 0.015 & 0.005 & 0.437 & 2.852 & 0.006 \\
\hline NPM (X3) & 0.008 & 0.007 & 0.174 & 1.129 & 0.263 \\
\hline
\end{tabular}

Source: data processed by the Author

The results of the t-test on GCG have a correlation coefficient value of 4.510 with a significance value of $0.000<0.05$ (significant) H3 is accepted. GCG partially positive and significant effect on the value of banking companies.

The results of the t-test on GCG have a correlation coefficient of 4.495 with a significance value of $0.038<0.05$ (significant) $\mathrm{H} 4$ is accepted. GCG partially has a positive and significant effect on the value of mining companies.

The results of the t-test have a correlation coefficient of 0.033 with a significance value of 0.263 > 0.05 (not significant) H5 is rejected. ROA partially has a positive but not significant effect on the value of banking companies.

The results of the t-test have a correlation coefficient value of 0.015 with a significance value of $0.006<0.05$ (significant) H6 is accepted. ROA partially positive and significant effect on the value of mining companies.

The results of the t-test have a correlation coefficient of 0.005 with a significance value of 0.899 > 0.05 (not significant) $\mathrm{H} 7$ is rejected. NPM partially has a positive but not significant effect on the value of banking companies.

The results of the t-test have a correlation coefficient of 0.008 , with a significance value of 0.263 $>0.05$ (not significant) H8 is rejected. NPM partially has a positive but not significant effect on the value of mining companies.

\section{Coefficient of Determination Test (Adjusted R2 Test)}

This test was conducted to test how far the ability of the independent variable in explaining the dependent variable is (Ghozali, 2016).

\section{Table 15: Coefficient of Determination Test Results (Adjusted R2) of Banking Companies

\begin{tabular}{|l|l|l|l|l|}
\hline Model & R & R Square & Adjusted R Square & Std. An error of the Estimate \\
\hline 1 & $.847^{\mathrm{a}}$ & .718 & .709 & .16363 \\
\hline
\end{tabular} \\ Source: data processed by the Author}

The result of the coefficient of determination above the adjusted $\mathrm{R}$ Square value is 0.709 , which means the magnitude of the effect of $\mathrm{GCG}(\mathrm{X} 1)$, $\operatorname{ROA}(\mathrm{X} 2), \mathrm{NPM}(\mathrm{X} 3)$ on $\operatorname{PBV}(\mathrm{Y})$ with $\mathrm{CSR}(\mathrm{Z})$ as the moderating variable is $70.9 \%$ and of $29.1 \%$ caused by other factors outside this regression. The adjusted $\mathrm{R}$
Square value is 0.709 meaning that the influence of GCG(X1), ROA(X2), NPM(X3) on firm value(Y) with $\mathrm{CSR}(\mathrm{Z})$ as the moderating variable as a strong moderating variable. As much as 0.291 can be caused by other factors that are not included in the regression model under study.

Table 16: Coefficient of Determination Test Results (Adjusted R2) of Mining Companies

\begin{tabular}{|l|l|l|l|l|}
\hline Model & R & R Square & Adjusted R Square & Std. An error of the Estimate \\
\hline 1 & $.901^{\mathrm{a}}$ & .812 & .801 & .15563 \\
\hline
\end{tabular}

Source: data processed by the Author 
The results of the coefficient of determination above the adjusted $\mathrm{R}$ Square value are 0.801 , the effect of $\operatorname{GCG}(\mathrm{X} 1)$, ROA(X2), $\mathrm{NPM}(\mathrm{X} 3)$ on $\mathrm{PBV}(\mathrm{Y})$ with $\mathrm{CSR}(\mathrm{Z})$ as the moderating variable is $80.1 \%$ and $19,9 \%$ caused by other factors outside this regression. The adjusted $\mathrm{R}$ Square value is 0.801 meaning that the influence of $\mathrm{GCG}(\mathrm{X} 1), \mathrm{ROA}(\mathrm{X} 2), \mathrm{NPM}(\mathrm{X} 3)$ on firm value $(\mathrm{Y})$ with $\operatorname{CSR}(\mathrm{Z})$ as the moderating variable is Strong. Another factor of 0.199 can be caused by other factors that are not included in the regression model under study.
Model Moderated Regression Analysis (MRA)

Interaction test or often called Moderated Regression Analysis (MRA) is a special application of linear multiple regression in which the regression equation contains an interaction element (multiplication of two or more independents) (Ghozali, 2016). The purpose of this analysis is to determine whether the moderating variable will strengthen or weaken the relationship between the independent variable and the dependent variable. The results of the MRA test data can be seen as follows:

Table 17: MRA Test Results of Banking Companies

\begin{tabular}{|c|c|c|c|c|c|}
\hline \multirow[t]{2}{*}{ Model } & \multicolumn{2}{|c|}{ Unstandardized Coefficients } & \multirow{2}{*}{$\begin{array}{l}\text { Standardized Coefficients } \\
\text { Beta }\end{array}$} & \multirow[t]{2}{*}{$\mathbf{t}$} & \multirow[t]{2}{*}{ Sig. } \\
\hline & $\mathbf{B}$ & Std. Error & & & \\
\hline (Constant) & 4.347 & .861 & & 5.046 & .000 \\
\hline GCG $(X 1)$ & 4.510 & .880 & .420 & 5.124 & .000 \\
\hline GCGCSR & 5.860 & .370 & 1.111 & 15.832 & .000 \\
\hline
\end{tabular}

Source: data processed by the Author

GCGCSR is the result of the interaction between GCG and CSR. The variable gives a positive correlation coefficient of 5.860 with a t-value of 15,832 and a significance value of $0.000<0.05$ (significant) H9 is accepted. CSR has succeeded in positively and significantly moderating the influence of GCG on banking firm value.

Table 18: MRA Test Results of Mining Companies

\begin{tabular}{|l|l|l|l|l|l|}
\hline \multirow{2}{*}{ Model } & \multicolumn{2}{|l|}{ Unstandardized Coefficients } & Standardized Coefficients & \multirow{2}{*}{ Sig. } \\
\cline { 2 - 6 } & B & Std. Error & Beta & & \\
\hline (Constant) & 4.613 & 2.121 & & 2.175 & .033 \\
\hline GCG (X1) & 4.495 & 2.126 & .195 & 2.114 & .038 \\
\hline GCGCSR & 6.498 & .442 & 1.040 & 14.715 & .000 \\
\hline
\end{tabular}

Source: data processed by the Author

GCGCSR is the result of the interaction between GCG and CSR. The variable gives a positive correlation coefficient of 6.498 with a t-value of 14,715 with a significance value of $0.000<0.05 \mathrm{H} 10$ is accepted. CSR has succeeded in moderating the influence of GCG on the value of mining companies.

Table 19: Results of MRA Test (Banking Companies)

\begin{tabular}{|l|l|l|l|l|l|}
\hline \multirow{2}{*}{ Model } & Unstandardized Coefficients & Standardized Coefficients & t & Sig. \\
\cline { 2 - 7 } & B & Std. Error & Beta & & \\
\hline (Constant) & 4.347 & .861 & & 5.046 & .000 \\
\hline ROA (X2) & .033 & .030 & .112 & 1.124 & .263 \\
\hline ROACSR & 3.559 & .327 & 10.733 & 10.896 & .000 \\
\hline
\end{tabular}

Source: data processed by the Author

ROACSR is the result of the interaction between ROA and CSR. The variable gives a positive correlation coefficient of 3.559 with a t-value of 10,896 and a significance value of $0.00<0.05 \mathrm{H} 11$ is accepted. CSR succeeded in moderating the influence of ROA on banking firm value.

Table 20: Results of MRA Test (Mining Companies)

\begin{tabular}{|l|l|l|l|l|l|}
\hline \multirow{2}{*}{ Model } & \multicolumn{2}{|l|}{ Unstandardized Coefficients } & Standardized Coefficients & t & Sig. \\
\cline { 2 - 4 } & B & Std. Error & Beta & & \\
\hline (Constant) & 4.613 & 2.121 & & 2.175 & .033 \\
\hline ROA (X2) & .015 & .005 & .437 & 2.852 & .006 \\
\hline ROACSR & .332 & .082 & 8.758 & 4.037 & .000 \\
\hline
\end{tabular}

Source: data processed by the Author

ROACSR is the result of the interaction between ROA and CSR. The variable gives a positive correlation coefficient of 0.332 with a t-value of 4.037 and a significance value of $0.000<0.05 \mathrm{H} 12$ is 
Lea Suraya \& Rilla Gantino, East African Scholars J Econ Bus Manag; Vol-5, Iss-1 (Jan, 2022): 22-34 accepted. CSR managed to moderate the effect of ROA on the value of mining companies.

Table 21: Results of MRA Test (Banking Companies)

\begin{tabular}{|l|l|l|l|l|l|}
\hline \multirow{2}{*}{ Model } & Unstandardized Coefficients & Standardized Coefficients & \multirow{2}{*}{ S } & & \\
\cline { 2 - 6 } & B & Std. Error & Beta & 5.046 & .000 \\
\hline (Constant) & 4.347 & .861 & & .127 & .899 \\
\hline NPM (X3) & .005 & .003 & .013 & 9.899 & .000 \\
\hline NPMCSR & .259 & .026 & 7.731 & \multicolumn{2}{|c}{ Source: data processed by the Author }
\end{tabular}

NPMCSR which is the result of the interaction between NPM and CSR has a positive correlation coefficient value of 0.259 with a t-value of 9.899 and a significance value of $0.000<0.05 \mathrm{H} 13$ is accepted. CSR succeeded in moderating the influence of NPM on banking firm value.

Table 22: Results of MRA Test (Mining Companies)

\begin{tabular}{|l|l|l|l|l|l|}
\hline \multirow{2}{*}{ Model } & \multicolumn{2}{|l|}{ Unstandardized Coefficients } & Standardized Coefficients & \multirow{2}{*}{ Sig. } \\
\cline { 2 - 7 } & B & Std. Error & Beta & & \\
\hline (Constant) & 4.613 & 2.121 & & 2.175 & .033 \\
\hline NPM (X3) & .008 & .007 & 174 & 1.129 & .263 \\
\hline NPMCSR & .426 & .072 & 8.858 & 5.912 & .000 \\
\hline
\end{tabular}

Source: data processed by the Author

NPMCSR is the result of the interaction between NPM and CSR. The variable giving a positive correlation coefficient value of 0.426 with a t-value of 5.912 and a significance value of $0.000<0.05 \mathrm{H} 14$ is accepted. CSR has succeeded in moderating the influence of NPM on the value of mining companies. $\mathrm{Y}=\alpha+\beta 1 \mathrm{X} 1+\beta 2 \mathrm{X} 2+\beta 3 \mathrm{X} 3+\beta 4(\mathrm{X} 1 \mathrm{X} 4)+\beta 5(\mathrm{X} 2$ $\mathrm{X} 4)+\beta 6(\mathrm{X} 3 \mathrm{X} 4)+\mathrm{e}$

Banking companies:

Nilai perusahaan $=\alpha+\beta 1(\mathrm{GCG})+\beta 2(\mathrm{ROA})+\beta 3$ $(\mathrm{NPM})+\beta 4(\mathrm{GCG} \times \mathrm{CSR})+\beta 5($ ROAx CSR $)+\beta 6$ $(\mathrm{NPM} \times \mathrm{CSR})+\mathrm{e}$

Nilai perusahaan $=4,347+4,510 \mathrm{GCG}+0,033 \mathrm{ROA}+$ $0,005 \mathrm{NPM}+5.860$ GCGCSR + 3.559 ROACSR + $0,259 \mathrm{NPMCSR}+\mathrm{e}$

Mining company

Nilai perusahaan $=\alpha+\beta 1(\mathrm{GCG})+\beta 2(\mathrm{ROA})+\beta 3$ $(\mathrm{NPM})+\beta 4(\mathrm{GCG} \times \mathrm{CSR})+\beta 5($ ROA $\times$ CSR $)+\beta 6$ $(\mathrm{NPM} \times \mathrm{CSR})+\mathrm{e}$

Nilai perusahaan $=4,613+4,495 \mathrm{GCG}+0,015 \mathrm{ROA}+$ $0,008 \mathrm{NPM}+6,498$ GCGCSR + 0,332 ROACSR + $0,426 \mathrm{NPMCSR}+\mathrm{e}$

\section{CONCLUSION AND SUGGESTIONS}

This study finds ROA in banking companies partially does not have a significant effect on firm value. The ROA obtained from net income on asset management is not significant because its value tends to decrease and is reasonably volatile in the 2016-2020 period and is relatively low in 2019 and 2020 NPM in banking companies partially does not have a significant effect on firm value. The decline in the NPM of banking companies obtained from the results of net income on the management of net interest income tends to be unstable, has decreased, and is feasible to fluctuate in 2016-2020 and is relatively low in 20192020. Fundraising and processing of funds for banking companies could not proceed according to the predetermined plan which resulted in a decrease in the value of ROA and NPM in banking companies. the bank was in trouble to increase the net profit from the management of its assets and at that time prioritized credit quality.

Research results from mining companies that have fluctuating values in 2016-2020 and low in 2019. 2020. Because 2019 is the implementation of the Presidential and Vice-Presidential election in Indonesia which has an impact on economic and political growth. Investors at that time were still holding back their funds to invest because they had not yet received certainty about the new regulatory arrangements and provisions. In addition, in 2020 there was slow and unstable economic growth due to restrictions on activities from the central government to parse the Covid-19 virus, so the projects and business strategies of mining companies could not run according to the predetermined plan which resulted in a decrease in the value of NPM so that mining companies cannot carry out banking operations optimally and projects are hampered which affect the value of the company.

The test results show the banking and mining sectors that generate GCG, ROA, NPM values, and through Corporate Social Responsibility activities, the company is running its business does not only pursue profit in terms of finance but has played a role in building a comprehensive and sustainable social economy. significant impact on the value of the company, with these results, the company will be encouraged to show its capacity in financial statements to gain legitimacy from the public for its intellectual property. This is in line with the theory of legitimacy. 
This recognition of public legitimacy is important for companies to maintain good financial reports. Good financial reports can provide information that is needed by shareholders to make shareholder decisions related to the valuation of a company which is stated in the share price. This is also closely related to the quality of the company's financial statements. Thus, CSR activities have shown the company's ability to generate profits, leading the company to get the highest maximum value because it affects the value of banking and mining companies. In line with the signaling theory, this becomes a signal that can be given by the company to give instructions to investors about the company's opportunities to increase and provide positive value. A higher company value will make it easier to enter the capital market because investors will catch positive signals from companies with greater growth so that a positive response reflects an increase in company value.

Based on the test results, it is expected that the company should be able to manage and optimize the use of its assets in generating higher profits so that the assessment of stakeholders in the company will have a significant effect so that the value of the company can increase. Through Corporate Social Responsibility, companies in running their business do not only pursue financial gain but also have a role to play in building a comprehensive and sustainable social economy. Because Corporate Social Responsibility activities or corporate social responsibility as a form of contribution in sustainable economic development, with company employees, families, and local communities to improve the quality of life. Through increasing Corporate Social Responsibility activities in the company, it will have a better influence on the company's business continuity which affects and can increase the value of the company because the level of trust between investors and the public will increase. This is because the implementation of Corporate Social Responsibility in the company can improve overall organizational performance, both in terms of company sales, financial performance, work stability, employee loyalty, company reputation. This will be an attraction for investors as an opportunity for the company in the future. This shows that high profits will provide good opportunities because it can trigger investors to invest their shares and increase the value of stakeholders which is expressed in the form of stock prices where the stock price is influenced by high stock demand from potential investors which affects the increase. the value of the company.

For investors and potential investors, if they want to invest, they should pay attention to the level of profit earned by the company and through the aspects of implementing good Corporate Social Responsibility

Cite This Article: Lea Suraya \& Rilla Gantino (2022). Comparison of the Influence of Good Corporate Governance, Return on Asset, Net Profit Margin on Company Value with Corporate Social Responsibility as Moderating Variables (Empirical Study on Banking and Mining Companies Listed on the Indonesia Stock Exchange 2016-2020). East African Scholars J Econ Bus Manag, 5(1), 22-34. activities, it can increase investor and community confidence to increase. The increasing disclosure of good Corporate Social Responsibility activities can increase investor confidence and the community will increase which will result in a good performance that can increase the value of the company.

\section{REFERENCES}

- Devie, D., Liman, L. P., Tarigan, J., \& Jie, F. (2018). Corporate social responsibility, financial performance and risk in Indonesian natural resources industry. Social Responsibility Journal.

- Ghozali, I. (2016). Aplikasi Analisis Multivariete Dengan Program IBM SPSS 23. Semarang: Badan Penerbit Universitas Diponegoro.

- Hergianti, A. N. (2020). Pengaruh Pertumbuhan Perusahaan, Profitabilitas Dan Leverage Terhadap Nilai Perusahaan. Jurnal Ilmu dan Riset Akuntansi, 9(1), 1-20.

- Houston, B. (2015). Signaling Theory. Angewandte Chemie International Edition, 6(11), 951-952.

- Kasmir. (2017). Analisis Laporan Keuangan. Jakarta: PT Rajagrafindo Persada.

- Latief, Z. (2018). Analisa Fundamental, Ilmu Investasi, Panduan Pemula. https://analis.co.id/pbvprice-to-book-value.html.

- Lukviarman, N. (2016). Corporate Governance. ed. Rachmi N Hamidawati. Solo: Era Adicitra Intermedia.

- Muharramah, R., \& Mohamad, Z. H. (2021). Pengaruh Ukuran Perusahaan, Leverage, Dan Profitabilitas Terhadap Nilai Perusahaan. 5(7), 569576.

- Niki, L. (2016). Lukviarman. (September).

- Purwanto, P., \& Jillian, A. (2017). Financial Performance towards Value of Firms in Basic and Chemicals Industry. European Research Studies Journal, 20(2), 443-60.

- Sawir, A. (2015). Analisis Kinerja Keuangan Dan Perencanaan Keuangan Perusahaan. Jakarta: PT Gramedia Pustaka Utama.

- Sudiani, N., \& Darmayanti, N. (2016). Pengaruh Profitabilitas, Likuiditas, Pertumbuhan, Dan Investment Opportunity Set Terhadap Nilai Perusahaan. None, 5(7), 245861.

- Ulum. (2017). Tinjauan Pustaka Dan Pengembangan Hipotesis.

- Wibawanto. (2016). Relevansi Nilai Informasi Akuntansi. Angewandte Chemie International Edition, 6(11), 951-952.

- William, R. S. (2015). Financial Accounting Financial Accounting.

- www.idx.co.id. 